\title{
Pediatric Study Indicator
}

National Cancer Institute

\section{Source}

National Cancer Institute. Pediatric Study Indicator. NCI Thesaurus. Code C123632.

An indication as to whether the study is a pediatric study. 